\title{
Developing a Personal Data Inventory Tracking and Managing System
}

\author{
luon-Chang Lin ${ }^{1,3, a}$, Yung-Wang Lin², Ling-Hsien Tseng ${ }^{3}$, Yeong-Chin Chen² \\ ${ }^{1}$ Department of Photonics and Communication Engineering, Asia University, Taiwan \\ ${ }^{2}$ Department of Computer Science and Information Engineering, Asia University, Taiwan \\ ${ }^{3}$ Department of Management Information Systems, National Chung Hsing University, Taiwan \\ aiclin@nchu.edu.tw
}

Keywords: PIMS, Information Law and Ethics, Digital Forensics.

\begin{abstract}
Constructing a PIMS (Personal Information Management System) is now organizations in Taiwan eagerly trying to do, to reach this goal personal data inventory tracking should take priority. This study developing a "Personal Data Inventory Tracking and Managing System" to help organizations control personal data type and data flow effectively. Using computer system to control personal data life circle not only can lower burdens of data owners, but also help managers to understand personal data deployment inside of the organizations in terms of which part of the data is useful while making choices or decisions. Organizations can also follow the system procedure as a personal data control standard in the future to help accord with the international standards and obey the Personal Data Protection Law of Taiwan in the perspectives of system design, management and operation procedures. Effectiveness of this system will remain to be measured and evaluated in the future.
\end{abstract}

\section{Introduction}

The integration of electronic technology and information are a vision people looking forward to and inevitable. However this trend also brings privacy arguments and information security issues, the complexity of electronization and digitalization makes personal data protection more important than before. Because of features such as massive storage, quick delivery and cross-comparison in this digital world, once personal data are disclosure the consequence will worse than before. Especially when personal data that include highly sensitive information such as medical history, sex life, gene, are disclosed, the data owner's privacy might be hurt and he/she could feel bad if others using those leaking data to critic him/her by his/her mental health, psychological status or other contagious disease issues [1].

This is why the United States, United Kingdom, European Union and Japan were eager to enforce personal data protection, and Taiwan also followed this world trend to modify its Personal Data Protection Law to emphasize personal data protection. Taiwan personal Data Protection Law was enforced in October 1st 2012(original version is named Computer-Processed Personal Data Protection Law) [2]. To reconcile personal right and reasonable data collection, processing and using, this law collect opinions from citizens and society, it also reference the law in developed countries to modify and expand the scale to all industries and organizations and person, enhanced law responsibility of companies and law violators, the impact was magnificent. The key policy is show on Table 1. The popularity of cloud computing in businesses world are increased dramatically, as a consequence personal data security will face more difficult challenges. To study how to protect personal data in this new global data protection era and to create a safe, reliable information environment are two of the most worth study issues.

Once the organization have personal data disclosed incident or other information security incident happened, the impact of corporate image damage and remedy will be catastrophic. Therefore, how organizations can handle those negative impacts come with modern technology and prevent 
individual personal data being collect, process, and use improperly are the initial motivations of this study.

Table 1: The differences between Personal Data Protection Law and Computer-Processed Personal Data Protection Law (arranged by the Author)

\begin{tabular}{|c|c|c|}
\hline Law Name & $\begin{array}{c}\frac{\text { Personal Information Protection }}{(\underline{\text { Act }}} \\
(\mathrm{New} \mathrm{Law})\end{array}$ & $\begin{array}{l}\text { Computer-Processed Personal } \\
\text { Data Protection Law } \\
\text { (Old Law) }\end{array}$ \\
\hline $\begin{array}{l}\text { Applicable } \\
\text { Target }\end{array}$ & $\begin{array}{l}\text { All industries(include Government } \\
\text { agency and Non-government } \\
\text { agency). }\end{array}$ & $\begin{array}{l}\text { Government agency, credit search } \\
\text { businesses, hospitals, schools, } \\
\text { telecommunication, financial, } \\
\text { securities, insurance, and mass } \\
\text { communications industries. }\end{array}$ \\
\hline Scope & $\begin{array}{l}\text { Information retrieval and } \\
\text { management by automatic or } \\
\text { non-automatic measures. }\end{array}$ & $\begin{array}{l}\text { The processing of personal data by } \\
\text { computers(use computers or } \\
\text { automatic machinery to key in, store, } \\
\text { compile, correct, search, delete, } \\
\text { output, or transmit data or process } \\
\text { otherwise). }\end{array}$ \\
\hline Damages & $\begin{array}{l}\text { 1. For each case of damages per } \\
\text { person shall not be less than NT } \$ 500 \\
\text { but not more than NT } \$ 20,000 \text {. } \\
\text { 2. The total amount of } \\
\text { compensation should not exceed } \\
\text { NT } \$ 200 \text { million. }\end{array}$ & $\begin{array}{l}\text { 1. For each case of damages per } \\
\text { person shall not be less than } \\
\text { NT } \$ 20,000 \text { but not more than } \\
\text { NT } \$ 100,000 \text {. } \\
\text { 2. The total amount of compensation } \\
\text { shall not be more than NT } \$ 20 \\
\text { million. }\end{array}$ \\
\hline $\begin{array}{c}\text { Public } \\
\text { Participation }\end{array}$ & $\begin{array}{c}20 \text { or more Parties may bring a Class } \\
\text { Litigation. }\end{array}$ & None \\
\hline Burden of proof & $\begin{array}{l}\text { Government agency and } \\
\text { Non-government agency }\end{array}$ & Compensation claimant \\
\hline
\end{tabular}

According to ISO 27001:2005, BS 10012:2009, Fig. 1, the core concepts of both standards are "PDCA". In ISO27001:2003 Plan-Do-Check-Active are the method using to create Information Security Management System, and BS 10012:2009 also applies "Plan-Do-Check-Act" (PDCA) cycle to establishing, implementing, operating, monitoring, exercising, maintaining, and improving the effectiveness of the PIMS system in organizations.

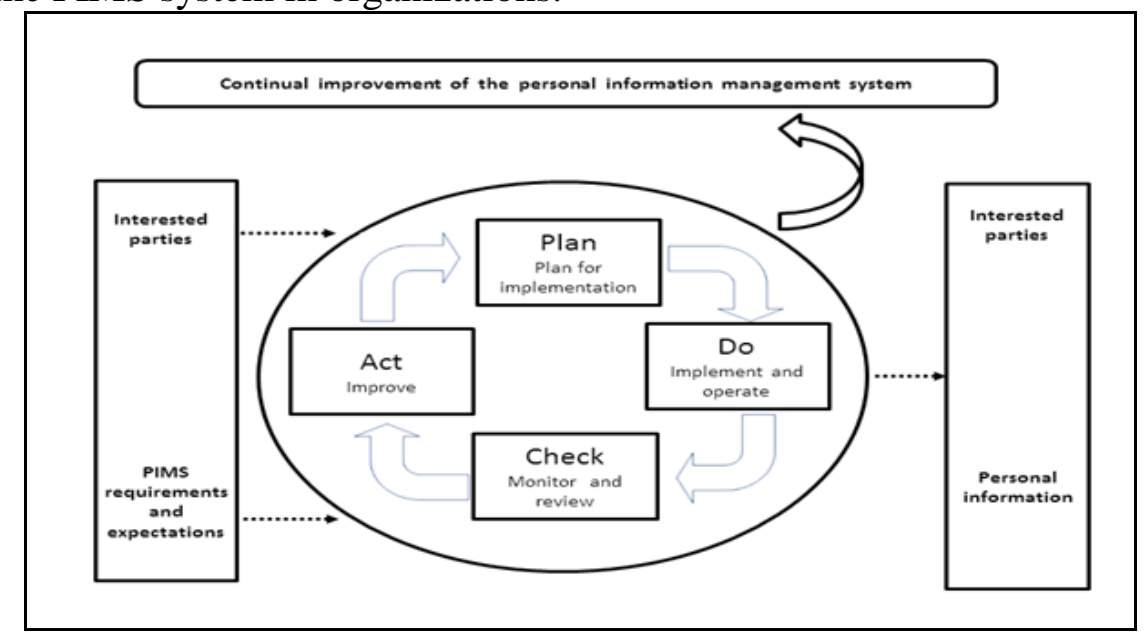

Fig.1:PDCA cycle applied to the management of personal information [3]. 
Therefore, organizations can follow PDCA (Plan-Do-Check-Act) Model to create personal information management system[4].

After organizations create personal data management policy, scale, and goal, organizations should enforce them, and according to the result to do the check and act step in PIMS. "Do" is the most important step in PIMS, in this step inventory counting is the first thing need to do. Through Inventory counting a personal data inventory list will be created. The concept of inventory counting can refer to the rule in Personal Data Protection Law and ISO 10012:2009 4.2.1, "An inventory of the categories of personal information processed by the organization shall be maintained. This inventory shall also document the purposes for which each category of personal information is used. " to protect and manage personal data based on the "collecting, processing, using, transmitting, destructing" steps in personal data life circle in managerial and technical perspectives to achieve the goal of personal data protection and to prevent the organization from violating the law. In present day, personal data inside organizations are massive and complicate, whether paper or electronic personal data from business execution, project planning, or activity enforcement are all needed to be protected. This study focuses on how to create a PIMS system for an organization concerning the situation (environment) of frequent business transaction, personnel change, risk management, and lawfulness.

Organizations can fulfill the requirement of PIMS by creating a "Personal Data Inventory Tracking and Managing System". Furthermore organizations can get related ISO certifications which may help increase customer relationships and corporate images, defend customer rights and benefits, and protect individual autonomy. To full manage the collection, processing and usage of personal data in modern technology society, organizations should start from using personal data inventory tracking system in information system design, cooperation management, and operation procedure to fulfill the request of PIMS. Protection awareness of individual privacy is rising; countries around the world also eagerly trying to execute the protection of personal data.

In 2012, the personal Data Protection Law modified and executed in Taiwan, which had tremendous impact to organizations involving in personal information collection, processing, or using. To protect personal data is also important to the development of corporate images. Personal data protection will become the most important issue of organization operation; this is why this study has been trying to construct a personal data inventory tracking system that helps organizations to manage personal data. Organizations can adjust according to the international standards and obey Personal Data Protection Law of Taiwan.

\section{Purpose and Research Field}

According to the introduction, this study trying to create "Personal Data Inventory Tracking and Managing System" which can separate to the "Data Owner Personal Data Inventory Tracking Sub System" and "Organization Personal Data Inventory Tracking Sub System." The data owner personal data inventory tracking sub system is for data of the organizations to responsibly count and track personal data, which data managers can import personal data, related digital or paper document, system information and user information to this sub system, the personal data manage method of this system can help employees in organizations to know how much personal data is in their control.

All the data in data owner personal data inventory tracking sub system will be gathered together to form an organization personal data inventory tracking sub system, which allows related supervisors, personal data manage department, or chairman of the personal data management committee to access this sub system. By summarize and analyse the data, users or managers will understand that the deployment of personal data inside organizations can help them make decisions, and follow this procedure to manage personal data in the future [5]. This study will focus on developing a data owner personal data inventory tracking sub system, and the organization personal data inventory tracking sub system will be discussed in the future.

The scope of personal data inventory tracking system in this study includes digital and paper personal data documents that organizations are collecting, processing, using, or transmitting when 
they execute businesses, execute tasks, create projects, process administrative procedures, or self-manage. The definition of personal data can be defined by organization individually or referring to the personal data protection law of Taiwan.

The purpose of personal data inventory tracking and managing system is to understand and examine personal data inside organizations(including types, purposes of collection, sources, columns, amounts, features, life circle activities, stakeholders, and risks), this will help clarify management responsibilities, ensure the control method and security maintenance plan, and analyze the legality of current personal data management .By this way, organizations can increase personal data protection efficiency and be easier to decide future management methods (such as de-identification masking, encryption, user access separation, and data reconstitution control method).

\section{System Model}

\section{Name of the System.}

The name of this system is personal data inventory tracking and managing system.

\section{Purpose of the System.}

The purpose of developing this system is to manage personal data inside organization and follow the design or the request of related law. This system not only provides the management of personal data but also be able to coordinate with other system and management interface. By developing this system, the following goals are expected to be reached:

i) To create a personal data inventory tracking and managing system to store all the activities and behavior records.

ii) To unify the standards of personal data inventory tracking, and decrease the difficulties of cross divisional cooperation in the future.

iii) To create the standard procedure of personal data inventory tracking, and lower the risks of personal data stealing, falsifying, destructing, disappearing, or leaking.

iv) To provide information retrieval services to fulfill the requirement of research and manage.

v) Using digital technique to provide diversify information form, especially allows to filing the paper form personal data.

vi) To create structured archiving to help tracking personal data incidents for precaution and correction, judicial evidence, or internal investigation.

vii) By combining personal data inventory tracking and risk analyze, organizations can use this system to cooperate with other system to manage risks. Through risk definition, risk estimation, risk classification, risk planning, and risk tracking to decide a balanced and integrated strategy, which can also be supervised.

viii) To fulfill the legality requests of the Personal Data Protection Law of Taiwan which can also become the corroboration of organization while adopt technical and organizing measures.

\section{System Structure Model.}

This system is for building inside of an organization, in particularly on its intranet, which can decrease the risk of viruses and hacker attacks. The system uses website interface that the users can use all of its functions by browser through intranet [6]. The system has three types of system structures, which are database management system, data owner personal data inventory tracking sub system, and organization personal data inventory tracking sub system. 


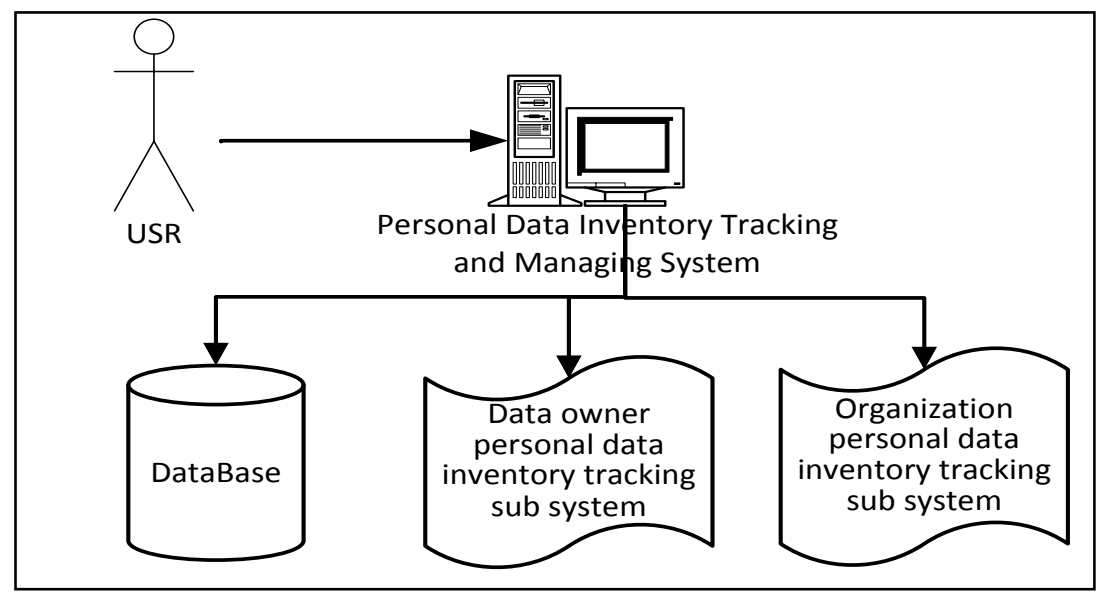

Fig. 2. System structure diagram.

\section{System Functions.}

This system focuses on the needs of personal data counting and tracking management and works on integrating the functions in adapt to process procedures of different usages. The functions include data establishment, data modification and maintenance, data classification, and access of data inventory results:

i) Personal data inventory establishment.

This function provides the users to build up personal data inventory and type in the detail accordingly, which can store the personal data that the users accessed during their work or project procedures.

ii) Personal data inventory maintenance.

This function allows the users to check stored personal data they built and allows them to modify the full individual personal data inventory form. Once the personal data belongs to them is modified or destructed, the database should also be updated.

iii) Personal data inventory classification.

This function provides classification and retrieving ability, which allows authorized users, personal data related department, and managers to check personal data inventory easily and quickly. The interface allows the users to retrieve personal data inventory via relative categories and key words.

iv) Personal data inventory result access and statistics.

The purpose of personal data inventory tracking system is to manage and record the scales, amounts, and conditions of personal data, so the system should provide database management function, personal data scan, and system integration. This function, according to users' habits, provides diagram and text for the users to access, and also allows the users to connect the image files in other personal data system and provides analysis function that the managers can access to control the condition of personal data counting and understand the feature and amount of personal data inside of the organizations. Report printing is also acquired in this function.

\section{System Users.}

Different levels of access are required in this system, so this system allows the primary user to set three types of user levels [7] :

i) Personal data processors: responsible for establishing, recording, or modifying personal data.

ii) Personal data controllers: including management department or senior managers, who are allowed to use the searching and analyzing function in this system that help them to understand the personal data flow inside of the organization and to make decisions.

iii) Personal data database manager: people in this level manage this system and modify the database according to the requests of the users and managers. 


\section{System Management.}

This system provides level management and log management functions, which help the system to be well managed. Level management function records the users level which ensure the security of the system. Log management records important information while the system is running, which information can be examined in the future.

Database Table Structure.

This system focus on create a data owner personal data inventory tracking sub system; its database table structure is shown as Table 2.

Table 2. Database table structure.

\begin{tabular}{|c|c|c|c|c|c|}
\hline Name & Type & $\begin{array}{l}\text { Required } \\
\text { Fields }\end{array}$ & $\begin{array}{l}\text { Multi-valu } \\
\text { ed field }\end{array}$ & $\begin{array}{l}\text { Pull-down } \\
\text { Menus } \\
\text { (Option) }\end{array}$ & Provider \\
\hline Identify Number & $\begin{array}{l}\text { VARCHAR2 } \\
\text { (20) }\end{array}$ & & & & System \\
\hline The Name of Party & $\begin{array}{l}\text { VARCHAR2 } \\
\text { (20) }\end{array}$ & * & & & Recorder \\
\hline Record of Unit & NUMBER(5) & * & & Y & Recorder \\
\hline $\begin{array}{l}\text { Information Processing } \\
\text { Type }\end{array}$ & $\begin{array}{l}\text { VARCHAR2 } \\
\text { (20) }\end{array}$ & $\star$ & () & Y & Recorder \\
\hline Source & $\begin{array}{l}\text { VARCHAR2 } \\
\text { (20) }\end{array}$ & * & (2) & Y & Recorder \\
\hline $\begin{array}{l}\text { Record History- Recorder } \\
\text { Name }\end{array}$ & $\begin{array}{l}\text { VARCHAR2 } \\
\text { (20) }\end{array}$ & * & & & System \\
\hline $\begin{array}{l}\text { Record History- Recorder } \\
\text { Date }\end{array}$ & NUMBER(10) & $\star$ & & & System \\
\hline $\begin{array}{l}\text { Record History- Modifier } \\
\text { Name }\end{array}$ & $\begin{array}{l}\text { VARCHAR2 } \\
\text { (20) }\end{array}$ & & & & System \\
\hline $\begin{array}{l}\text { Record History- Modifier } \\
\text { Date }\end{array}$ & NUMBER(10) & & & & System \\
\hline Latest Update & NUMBER(10) & * & & & System \\
\hline Sensitive Information & $\begin{array}{l}\text { VARCHAR2 } \\
\text { (20) }\end{array}$ & & (2) & Y & Recorder \\
\hline Purpose & $\begin{array}{l}\text { VARCHAR2 } \\
\text { (20) }\end{array}$ & * & (2) & Y & Recorder \\
\hline Classification & NUMBER(10) & $\star$ & () & Y & Recorder \\
\hline Basis & $\begin{array}{l}\text { VARCHAR2 } \\
\text { (20) }\end{array}$ & $\star$ & () & Y & Recorder \\
\hline Collection Type & $\begin{array}{l}\text { VARCHAR2 } \\
\text { (20) }\end{array}$ & $\star$ & & Y & Recorder \\
\hline Collection Name & $\begin{array}{l}\text { VARCHAR2 } \\
\text { (20) }\end{array}$ & $\star$ & & & Recorder \\
\hline Store location & $\begin{array}{l}\text { VARCHAR2 } \\
\text { (20) }\end{array}$ & * & () & & Recorder \\
\hline Backup & $\begin{array}{l}\text { VARCHAR2 } \\
\text { (20) }\end{array}$ & & (0) & & Recorder \\
\hline Internally Transmit & $\begin{array}{l}\text { VARCHAR2 } \\
\text { (20) }\end{array}$ & & () & & Recorder \\
\hline Delete or Destroy & $\begin{array}{l}\text { VARCHAR2 } \\
\text { (20) }\end{array}$ & $\star$ & (2) & & Recorder \\
\hline
\end{tabular}




\begin{tabular}{|c|c|c|c|c|c|}
\hline Internal Organization & $\begin{array}{l}\text { VARCHAR2 } \\
\text { (20) }\end{array}$ & * & () & Y & Recorder \\
\hline Commissioning Agency & $\begin{array}{l}\text { VARCHAR2 } \\
\text { (20) }\end{array}$ & & () & & Recorder \\
\hline Provider & $\begin{array}{l}\text { VARCHAR2 } \\
\text { (20) }\end{array}$ & & () & & Recorder \\
\hline Others & $\begin{array}{l}\text { VARCHAR2 } \\
\text { (20) }\end{array}$ & & () & & Recorder \\
\hline Retention Period & NUMBER(10) & $\star$ & & $\mathrm{Y}$ & Recorder \\
\hline Quantity & NUMBER(10) & $\star$ & & & Recorder \\
\hline Confidentiality & $\begin{array}{l}\text { VARCHAR2 } \\
\text { (20) }\end{array}$ & * & & Y & Recorder \\
\hline Integrity & $\begin{array}{l}\text { VARCHAR2 } \\
\text { (20) }\end{array}$ & * & & Y & Recorder \\
\hline Availability & $\begin{array}{l}\text { VARCHAR2 } \\
\text { (20) }\end{array}$ & $\star$ & & Y & Recorder \\
\hline Publicize the Items & $\begin{array}{l}\text { VARCHAR2 } \\
\text { (20) }\end{array}$ & * & & Y & Recorder \\
\hline Rights of the Party & $\begin{array}{l}\text { VARCHAR2 } \\
\text { (20) }\end{array}$ & * & & Y & Recorder \\
\hline $\begin{array}{l}\text { Any Request to } \\
\text { Discontinue Collection, } \\
\text { Processing or Use of the } \\
\text { personal information }\end{array}$ & $\begin{array}{l}\text { VARCHAR2 } \\
\text { (20) }\end{array}$ & $\star$ & & $\mathrm{Y}$ & Recorder \\
\hline $\begin{array}{l}\text { Any Inquiry and Request } \\
\text { for a Review of the } \\
\text { personal information }\end{array}$ & $\begin{array}{l}\text { VARCHAR2 } \\
\text { (20) }\end{array}$ & $\star$ & & Y & Recorder \\
\hline $\begin{array}{l}\text { Any Request to } \\
\text { Supplement or Correct of } \\
\text { the personal information }\end{array}$ & $\begin{array}{l}\text { VARCHAR2 } \\
\text { (20) }\end{array}$ & $\star$ & & $\mathrm{Y}$ & Recorder \\
\hline Regularly Review & $\begin{array}{l}\text { VARCHAR2 } \\
\text { (20) }\end{array}$ & * & (0) & Y & Recorder \\
\hline
\end{tabular}

\section{Conclusion and Suggestion}

Based on personal data protection issues and the researcher's system analysis experiences, this study, from system analysis perspective, suggests several functions that a personal data inventory tracking system should contain. Then according to the international standards and related laws in Taiwan, the researcher determines the database structure that fulfills the request of BS10012 and Personal Data Protection Law of Taiwan. By tracking personal data used in this system or personal data usages, data flow and log can be recorded to control the collecting, processing, and using of the personal data without being affected by the great amount of personal data accumulated over time. This system can also work together with ISMS system in ISO 27001 to construct protection of an information system, or work with other risk management tools to manage the risks. In such cases, the system will help organizations to understand the risks and reinforce their cooperation operation, data loss prevention, and information security abilities.

In this study, personal data inventory tracking system practically offers profound assistance to organizations, and the measurements of operation and function efficiency will be discussed in the future study. 


\section{References}

[1] C. P. Waegemann: Spotlight on Healthcare: Document Imaging in Healthcare: One Piece of the Puzzle in Creating Electronic patient Record Systems. Inform, Vol. 14-1 (2000), pp.8-11.

[2] Laws \& Regulations Database of The Republic of China: Personal Information Protection Act, Information on http://law.moj.gov.tw/ENG/LawClass/LawAll.aspx?PCode=I0050021

[3] The British Standards Institution: BRITISH STANDARD BS10012:2009 Data protection -Specification for a personal information management system, Information on http://img.21food.cn/img/biaozhun/20100729/187/11294278.pdf

[4] Arne Roock: Applying the PDCA Cycle in knowledge work, (2012). Information on http://p-a-m.org/2012/10/applying-the-pdca-cycle-in-knowledge-work/

[5] Gong Jhen, in: System Analysis and Design, Taiwan: Kao-Une Press, (2010).

[6] C.-H. Yan, in: Database System, Taiwan : GOTOP Press, (2013).

[7] J.W. Satzinger, R.B. Jackson, S.D. Burd, in: Systems Analysis \& Design in a Changing World, Sixth Edition, Boston: Course Technology Press, (2011). 